\title{
MENGENAL SISTEM PENGETAHUAN, TEKNOLOGI, DAN EKONOMI NELAYAN PANTAI UTARA JAWA
}

\author{
Singgih Tri Sulistiyono*
}

\begin{abstract}
Abstrak
Bahwa budaya masyarakat nelayan merupakan 'sea-side culture' yang paling tua dalam khasanah budaya bahari. Meskipun dalam sejarah budaya masyarakat nelayan di pantai utara Jawa mengalami perkembangan yang lamban jika dibandingkan dengan sektor kebaharian yang lain (seperti perkapalan dan perdagangan) namun budaya masyarakat nelayan juga mengalami perkembangan sejalan dengan modernisasi yang merebak di sektor-sektor yang terkait. Faktor ekologis telah memprekondiskan corak budaya nelayan merupakan budaya yang khas jika dibandingkan dengan berbagai komunitas di sekitarnya. Kekhasan budaya nelayan dapat dilihat antara lain dari unsur budaya yang terkait dengan sistem pengetahuan, teknologi, dan ekonomi mereka, seperti sistem bagi hasil, pengetahuan tentang posisi dan arah di tengah laut, iklim dan cuaca, arah arus dan angin, teknologi prahu, berbagai jenis alat tangkat, dan teknologi pengolahan ikan.
\end{abstract}

\section{Kata Kunci: Sistem Pengetahuan, Teknologi, Ekonomi Nelayan, Pantai Utara Jawa}

\section{Pendahuluan}

Tulisan ini akan mencoba untuk mendeskripsikan secara umum sistem pengetahuan, teknologi, dan ekonomi nelayan khnususnya di kawasan pantai utara (pantura) Jawa bagian tengah dan timur. Pemahaman terhadap isu ini sangat signifikan dalam rangka mengenal lebih lanjut masyarakat dan budaya nelayan yang merupakan salah satu elemen sosial yang sangat penting dalam masyarakat Indonesia. Signifikansi pengenalan terhadap masyarakat dan budaya nelayan juga sangat diperlukan mengingat banyak orang melihat masyarakat nelayan sebagai kelompok masyarakat yang miskin secara ekonomi dan tertinggal dari sisi pengetahuan dan teknologi serta 'tersingkir' secara secara kultural. ${ }^{1}$ Hal itu, misalnya, dapat dilihat dari ungkapan 'cerak watu adoh ratu' (dekat dengan batu jauh dari raja). ${ }^{2}$ Padahal sebagai sebuah komunitas yang khas, mereka sesungguhnya telah mengembangkan budaya yang khas pula yang berbeda dengan jenis budaya mesyarakat lain. Dalam hal ini budaya mereka juga bisa dikatakan telah memiliki apa yang oleh C. Kluckhohn disebut sebagai 'tujuh unsur kebudayaan universal' yang

${ }^{*}$ Singgih Tri Sulistiyono adalah Dosen Jurusan Sejarah Fakultas Ilmu Budaya Universitas Diponegoro Semarang.

1 Selama ini ada anggapan bahwa 'kemiskinan nelayan' merupakan suatu kebenaran, lihat Masyhuri, 'Iptek dan Dinamika Ekonomi Nelayan', dalam: Bondan Kanumoyoso, dkk. (penyunting), Kembara Bahari: Esei Kehormatan 80 Tahun Adrian B. Lapian (Jakarta: Komunitas Bambu, 2009), hlm. 58.

2 Lihat Pujo Semedi, Close to the Stone, Far from the Throne: The Story of A Javanese Fishing Community 1820s-1990s (Yogyakart: Benang Merah, 2003), hlm. 301. 
mencakup bahasa, sistem teknologi dan alat produksi, sistem mata pencaharian hidup (ekonomi), sistem organisasi sosial, sistem pengetahuan, sistem religi, dan kesenian. ${ }^{3}$

Sudah barang tentu unsur-unsur kebudayaan masyarakat nelayan tersebut bukanlah merupakan sesuatu yang statis sebagaimana yang sering digambarkan oleh banyak orang. Budaya mereka juga mengalami perubahan-perubahan secara diakronis dari masa ke masa sebagai dampak baik dari dinamika internal maupun ekspansi kekuatan eksternal. Selain itu perubahan pada salah satu aspek kebudayaan juga akan berpengaruh terhadap aspek kebudayaan yang lain. Dalam hubungan itu, makalah ini akan memfokuskan kajian pada tiga dari tujuh unsur kebudayaan masyarakat nelayan di pantura Jawa bagian tengah dan timur yaitu yang terkait dengan sistem pengetahuan, teknologi dan alat produksi, dan ekonomi. Ketiga unsur kebudayaan universal pada masyarakat nelayan pantura Jawa tersebut akan ditinjau secara diakronis yang menekankan pada aspek-aspek sejarah dan perkembangannya. Perlu juga ditekankan di sini bahwa perubahan pada salah satu unsur kebudayaan juga akan memprekondisikan perubahan pada unsur-unsur kebudayaan yang lain. Dalam hal ini antara sistem pengetahuan, teknologi dan ekonomi

3 Koentjaraningrat, Pengantar Ilmu Antropologi (Jakarta: Rineka Cipta, 1990), hlm. 203-204. memiliki keterkaitan yang sangat erat serta saling mempengaruhi. Dalam konteks itu makalah ini akan membahas beberapa hal, yaitu kondisi ekologis dan potensi ekonomi pantura Jawa, kejayaan sejarah pantura Jawa, dan perkembangan sistem pengetahuan dan teknologi serta ekonomi masyarakat nelayan di pantura Jawa.

\section{Ekologi dan Ekonomi}

Laut Jawa membentang antara Pulau Jawa, Sumatera, Kalimantan, Sulawesi, dan Bali dan Lombok. Laut ini berbatasan dengan Selat Karimata dan Selat Sunda di sebelah barat dan di sebelah timur berbatasan dengan Selat Makassar dan Laut Bali. Batas sebelah utara adalah Pulau Kalimantan, sedangkan Pulau Jawa adalah perbatasan selatan. Laut Jawa memanjang lebih dari 800 mil dari timur ke barat, dengan luas rata-rata 250 mil. ${ }^{4}$ Laut ini memiliki luas secara keseluruhan sekitar 320.000 kilometer persegi dengan kedalaman sekitar 40-50 m. ${ }^{5}$

4 A.G. Findlay, $A$ Directory for the Navigation of the Indian Archipelago and the Coast of China from the Straits of Malacca and Sunda, and thePpassage East of Java to Canton, Shanghai, the Yellow Sea, and Korea (London: Laurie, 1889), hlm. 699.

5 W. Rodhes (ed.), The Encyclopedia of Oceanography (New York: Reinhold, 1966) 424429. See also C. Boissevain, Tropisch Nederland: Indrukken Eener Reis door Nederlandsch-Indië (Harleem: Tjeenk Willink, 1909) 50. The central point of the Java Sea lies on 112 East longitude and 5 South latitude. 
Kondisi alam pantai Laut Jawa sangat heterogen. Pantai utara Jawa umumnya datar, di mana pohon besar bahkan dapat tumbuh di sepanjang pantai. Pada zaman dahulu orang masih sangat sulit untuk memasuki pedalaman Jawa melalui pintu pantura Jawa. Ada beberapa puncak gunung, yang dapat berfungsi sebagai seamarks. Beberapa puncak ini berasal dari ketinggian 10.000 sampai 11.000 kaki. Tanda alam ini sangat penting bagi pelaut khususnya untuk pelayaran prahu tradisional dan nelayan. Pantai di utara pulau Jawa umumnya berlumpur dan berpasir. 6

Pantai Laut Jawa yang terletak di pulau Sumatra meliputi pantai Palembang, Lampung, Selat Bangka, dan Selat Sunda. Secara umum, seluruh pantai laut Jawa di di Palembang rendah, padat ditutupi oleh hutan.7 Sementara itu pantai Laut Jawa yang ada di Pulau Bangka mengandung bebatuan yang keras. Ada dua sungai yang dapat dilayari menuju Palembang untuk kapalkapal kecil yaitu sungai Musi dan Asin. Tidak seperti Palembang, tidak terdapat sungai besar di Teluk Betung. Kota ini terletak di Teluk Lampung yang berfungsi sebagai tempat berlindung dan jalan yang baik untuk Teluk Betung. ${ }^{8}$

${ }^{6}$ Findlay, A directory, hlm. 648.

7 H. Blink, Nederlandsch Oost- en WestIndië: Geographisch, Etnologisch en Economisch Beschreven, tweede deel (Leiden: Brill, 1907), hlm. 2-3.

${ }^{8}$ Findlay, A directory, hlm. 73.
Pantai Laut Jawa di Kalimantan memiliki karakteristik dominan. Hampir seluruh pantai selatan dan barat Kalimantan berlumpur dan rawa. Oleh sebab itu pada awalnya tidak ada kota di pantai di Kalimantan. Banjarmasin, misalnya, terletak sekitar 13 mil dari pantai, sementara itu Pontianak terletak sekitar 12 mil dari muara Sungai Mahakam yang dapat dilayari. Barito dan Martapura merupakan sungai yang dapat dilayari mencapai Banjarmasin. Kota ini terletak di tepi Sungai Martapura, anak Sungai Barito. ${ }^{9}$

Dibandingkan dengan pantai-pantai di Kalimantan, pantai sekitar Makassar memiliki sedikit kendala seperti lumpur dan rawa-rawa. Sebagian besar kawasan di sekitar pelabuhan ini memiliki perairan dalam, kapal dapat berlabuh dengan mudah. Inilah sebabnya mengapa selama pemerintahan kolonial Belanda Makassar dijadikan sebagai pelabuhan besar untuk kapal uap dan pelabuhan utama di kapal berlayar di bagian timur kepulauan Indonesia. 10

Faktor alamiah telah memungkinkan Laut Jawa mengandung plankton yang sangat kaya yang pada gilirannya menjadi tempat yang nyaman bagi ikan untuk berkembang. Oleh sebab itu Laut Jawa juga

9 Allied Geographical Section, Southwest Pacific Area, Terrain Handbook 63: Bandjermasin (30 March 1945), hlm. 7-9. See also J. Paulus, Encyclopaedie van Nederlands-Indië (The Hague: Nijhoff, 1917), hlm. 137.

10 Findlay, A directory, hlm. 782. 
memiliki potensi perikanan yang kaya pula. ${ }^{11}$ Diperkirakan terdapat sekitar 1.500 hingga 3.000 spesies kehidupan laut di kawasan Laut Jawa baik dari jenis pelagic maupun demersal (dasar laut). Menurut catatan pada tahun 1984, potensi hasil tangkapan ikan demersal di Laut Jawa adalah 738.320 metrik ton/tahun dan ikan pelagis sebanyak 624.840 metrik ton/tahun. ${ }^{12}$ Selama ini, berbagai jenis ikan yang ditangkap di kawasan Laut Jawa antara lain layur, tengiri, tongkol, kakap, belanak, bawal, kembung, dorang, cucut, manyung, lemuru, dan sebagainya. Dengan potensi kekayaan ikan tersebut, maka pada tahun 1991 misalnya, Laut Jawa memiliki andil 30 persen dari produksi perikanan di tingkat nasional. ${ }^{13}$ Selain itu sekitar 60 persen nelayan di Indonesia melakukan operasi di kawasan Laut Jawa. Oleh karena itu tidak mengherankan jika nelayan merupakan mata pencaharian yang sangat penting bagi masyarakat pantai utara Jawa dan daerah sekeliling Laut Jawa yang lainnya. Terdapat

11 Masyhuri, Menyisir Pantai Utara Jawa: Usaha dan Perekonomian Nelayandi Jawa dan Madura, 1850-1940 (Jakarta: Pusaka Nusatama, 1996), hlm. 26-27.

12 Sutejo K. Widodo, Ikan Layang Terbang Menjulang: Perkembangan Pelabuhan Pekalongan menjadi Pelabuhan Perikanan19001990 (Semarang: BP UNDIP-Toyota Foundation, 2005), hlm. 35.

13 B. Sadhotomo \& J.R. Durand, "General Features of Java Sea Ecology", dalam: file://localhost/C:/Users/LABSEJ 1/AppData/L ocal/Temp/010017248.pdf (Dikunjungi tanggal 15 Juni 2010). sekitar 2 juta nelayan di pantai utara Jawa. ${ }^{14}$ Namun demikian pertumbuhan jumlah nelayan yang begitu besar diiringi dengan cara eksploitasi kekayaan perikanan yang tidak sustainable menyebabkan kawasan laut Jawa menjadi daerah yang disebut overfishing. ${ }^{15}$ Dalam hubungan itu pula muncullah paradok bahwa kemiskinan nelayan terjadi di tengah-tengah kawasan laut yang kaya. Hampir sebagian besar nelayan masih hidup dalam kemiskinan, bahkan mereka masih hidup di bawah garis kemiskinan. Pada tahun 1996/1997 misalnya, pendapatan nelayan antara $\mathrm{Rp}$ $82.000,00$ - Rp 200.000,00 per bulan. Jumlah tersebut masih jauh di bawah UMR (Rp 380.000,00) per bulan. ${ }^{16}$

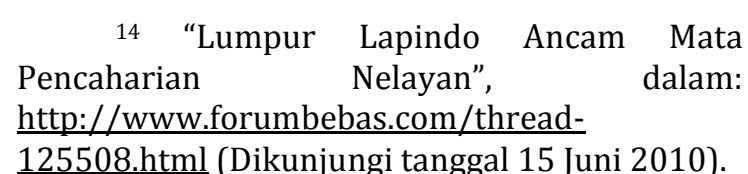

15 William D. Sunderlin, "Beyond Mathusian Overfishing: The Importance of Structural and Non-demographic Factors", Traditional Marine Resources Management and Konowledge Information Bulletin (4 September 1994), 3, dalam: http://docs.google.com/viewer?a=v\&q=cache:0 UqqY4hfz7cl: 202.0.157.3/ coastfish/Sections/reef/Library/InfoBull/TRAD /4/TRAD4-2-Sun.pdf+over+fishing+java\&hl =id\&gl=id\&pid $=\quad$ bl\&srcid $=\quad$ ADGEESi697kGWC5joGGJ6mn2JX8fmMm8ZHjrUM0Z yMi0FUbTOlPoMYyjHjlJPkKT5BckHPlifAr 7Cb7s2CoKS9c YpGf40iuIwrs5RCJeHPYDcmyEe2 M8zUI1rYvkXgI0aMPKY946Vt\&sig=AHIEtbRuCa 2-ubDlfHyvmpPiMFzWcYj54A

16 "Kemiskinan Nelayan, dalam: http://luckyfish06.co.cc/2009/10/kemiskinannelayan/. Lihat juga Mohammad Takdir Ilahi, "Kemiskinan Nelayan". http://koran.republika.co.id/koran/0/107854/ Kemiskinan Nelayan 
Ada sesuatu yang terlupa bahwa konsep nelayan itu sendiri sebetulnya bukanlah merupakan suatu konsep yang monolitik. Apa yang disebut sebagai 'nelayan' sebetulnya merupakan suatu konstruksi masyarakat yang cukup complicated. Dalam hubungan ini, tidak semua nelayan hidup di bawah garis kemiskinan. Ternyata terdapat kelompok tertentu dari nelayan yang kaya atau bahkan sangat kaya bergantung dari posisi mereka dalam masyarakat nelayan itu sendiri dan posisi itu banyak ditentukan oleh penguasaan atas alat-alat produksi. Pada masyarakat nelayan desa Ujungwatu misalnya, terdapat tiga kelas sosial yang memiliki perbedaan yang cukup signifikan, yaitu kelompok nelayan kaya (juragan darat), nelayan sedang (juragan laut), dan nelayan miskin (nelayan buruh/pandega/jurag). Pertama, juragan darat terdiri dari para nelayan kaya yang memiliki seluruh peralatan melaut seperti perahu, motor tempel, jaring dan peralatan laut lainnya, tetapi mereka tidak secara langsung ikut melaut. Kedua, juragan laut termasuk kelompok nelayan menengah yang memilki peralatan melaut tetapi mereka selalu melaut sebagai pimpinan perahu/nahkoda. Ketiga, kelompok nelayan miskin atau nelayan buruh yang tidak memiliki peralatan utama melaut, sehingga mereka selalu bekerja pada juragan darat atau juragan laut. ${ }^{17}$ Namun demikina menurut Masyhuri bahwa terdapat kecenderungan peningkatan kemakmuran di antara para nelayan. Hal itu bisa dilihat dari semakin banyaknya jumlah juragan laut dan juragan darat dan tentu saja juga jumlah pandega. ${ }^{18}$

Sistem bagi hasil dengan alat purse seine mini adalah hasil total dikurangi terlebih dahulu dengan pengeluaran yang terdiri dari retribusi sebesar 3 persen ditambah biaya untuk asuransi, tabungan kematian, dan tabungan paceklik. Setelah itu dikurangi biaya perbekalan dan sangu serta untuk pemeliharaan alat sebesar 15 persen. Sisanya kemudian dibagi menjadi 2 yaitu 50 persen untuk juragan dan 50 persen untuk ABK (Anak Buah Kapal). ${ }^{19}$

\section{Kejayaan Sejarah Pantura}

Dengan potensi kekayaan laut yang sangat besar dan didukung pula oleh kesuburan daratan Jawa serta jumlah penduduk yang padat ditambah lagi dengan pertumbuhan penduduk yang relatif cepat telah

17 Sugiyarto, "Perubahan Pandangan Bekerja Masyarakat Nelayan Desa Ujungwatu, Jepara", dalam: http://www.google.co.id/search?q=ujung+watu + jepara\&ie $=$ utf-8\&oe $=$ utf-8\&aq $=$ t\&rls=org.mozilla:id:official\&client=firefox-a 18 Masyhuri, Iptek dan Dinamika, hlm. 60.

19 A. Dwihendrosopno, "Dampak Modernisasi Alat Tangkap Ikan Terhadap Sistem Bagi Hasil Nelayan Di Desa Gempolsewu Kecamatan Rowosari Kabupaten Kendal", artikel Hibah Penelitian Jurusan Sejarah Fakultas Ilmu Humaniora Universitas Diponegoro, 2009. 
menempatkan pulau Jawa khususnya kawasan pantura memiliki peran yang besar dalam sejarah Jawa khususnya dan sejarah Indonesia bahkan Asia Tenggara pada umumnya. Sebelum kedatangan bangsabangsa kolonialis, kawasan pantai utara Jawa memegang peran yang sangat signifikan dalam dinamika kebaharian di Nusantara.

Seperti diketahui bahwa sekitar abad ke-7 masehi di kawasan Nusantara bagian barat telah berkembang kerajaan Sriwijaya. Perkembangan kerajaan ini sejalan dengan perkembangan kekuasaan politik di Jawa Tengah (Kerajaan Mataram). Oleh sebab itu kompetisi dan konflik tidak dapat dihindari. Kompetisi dan konflik antara Sriwijaya dan kerajaan-kerajaan di Jawa menunjukkan intensitas tinggi ketika pusat kerajaan Mataram dipindahkan dari Jawa Tengah ke Jawa Timur. Raja Sendok (929-947), telah memindahkan istana dan ia diakui sebagai pendiri dinasti baru (Isyana) yang memerintah di Jawa Timur sampai 1222. Salah satu motif pemindahan ini adalah untuk menghindari konflik dengan Sriwijaya. Munculnya kekuatan politik di Jawa Timur memberikan dampak yang signifikan bagi perekonomian daerah di kawasan pantura Jawa bagian timur pada khususnya dan kepulauan Indonesia pada umumnya. $^{20}$ Berbeda dengan kerajaan

20 O.W. Wolters, 'Studying Srivijaya', JMBRAS 2 (52) (1979), hlm. 6. Lihat juga H.G.
Mataram di Jawa Tengah yang sangat bergantung pada ekonomi pertanian sawah, wilayah pesisir dan lembah-lembah sungai di Jawa Timur belum belum berkembang sebagai daerah-daerahpertanian yang surplus yang dapat mendukung kekuatan politik kerajaan baru ini. Oleh karena itu, sejak periode awal raja-raja Jawa Timur memberi perhatian yang lebih terhadap perdagangan maritim. Hubungan perdagangan diselenggarakan baik dengan kawasan timur kepulauan Indonesia (seperti Maluku) maupun dengan kawasan bagian barat (seperti dengan orang-orang Sumatra dan Semenanjung Malaya yang pada waktu itu masih di bawah dikuasai oleh kerajaan Sriwijaya).

Selama masa pemerintahan raja Dharmawangsa Teguh (985-1006), terjadi peningkatan konflik ekonomi dan politik antara Jawa dan Sriwijaya. Serangan pasukan Dharmawangsa terhadap Sriwijaya telah menempatkan kerajaan maritim ini pada 'posisi berbahaya'. Hanya dengan membangun hubungan baik dengan kerajaan Cola (India) dan Cina akhirnya Sriwijaya mampu melakukan serangan balik terhadap pasukan Dharmawangsa. Bahkan konspirasi yang didalangi oleh Sriwijaya (dengan salah satu pengikut Dharmawangsa) bisa menghancurkan istana Dharmawangsa dan membunuhnya pada Influence Abroad', JMBRAS 1 (51) (1978), hlm. 5. 
tahun 1006 dalam sebuah insiden yang populer disebut sebagai pralaya. ${ }^{21}$

Hubungan baik antara Sriwijaya dengan Chola tidak berlangsung lama. Pada tahun 1007 Kerajaan Chola mulai melakukan ekspansi ke wilayah timur. Pada 1025 ibukota Sriwijaya diserang. Selama agresi berikutnya di tahun 1027, raja Sriwijaya (Sanggramawiyottunggawarman) dapat ditangkap. Tidak ada catatan tentang nasib raja ini. Setelah jatuhnya istana Sriwijaya, serangan berikutnya diarahkan ke daerah Sriwijaya di Semenanjung Malaya. Kelemahan Sriwijaya sebagai akibat dari agresi Kerajaan Chola telah menimbulkan dua dampak yang signifikan. Pertama, penerus Dharmawangsa, yaitu Airlangga (1019-1042) dapat merebut kembali daerah-daerah yang melepaskan diri setelah peristiwa pralaya pada tahun 1006. Kedua, serangkaian serangan Chola mungkin memberikan kesadaran kepada penguasa Sriwijaya kemitraan yang baik dengan Kerajaan Chola bisa berubah menjadi perang dan penaklukan. Hal ini menjadi pendorong bagi munculnya 'gentlement agreement ' di antara kekuatan utama di Dunia Melayu dan Dunia Jawa. Situasi ini menjadi semakin mengkristal ketika dua kekuatan ini bersekutu untuk menghadapi kerajaan Cola melalui perkawinan politik antara Airlangga (penerus Dharmawangsa)

21 D.G.E. Hall, Sejarah Asia Tenggara (Surabaya: Usaha nasional, 1988), hlm. 66. dan seorang saudara perempuan raja Sriwijaya. Ada semacam konsensus di mana Sriwijaya mengontrol bagian barat Nusantara, sementara bagian timur berada di bawah kontrol oleh Airlangga. Namun demikian Jawa sebenarnya masih juga memiliki hubungan perdagangan dengan bagian barat wilayah Nusantara. 22

Gelombang ekspansi Jawa semakin meningkat kembali ketika Kertanegara memegang tampuk kekuasaan sebagai raja Singasari (Jawa Timur) pada tahun 1268. Dengan meneruskan tradisi politik Jawa yang anti dominasi Cina, ia mencoba untuk memperluas pengaruhnya dengan membentuk aliansi militer dan politik di antara kekuatan-kekuatan di Nusantara. Dia menyadari bahwa Cina adalah kekuatan raksasa yang harus dihadapi bersama. Dia ingin menampilkan Singasari sebagai kekuatan baru di Nusantara (termasuk dunia Jawa dan dunia Melayu). Dia menggantikan semua pejabat yang tidak sejalan dengan ambisinya. Kerajaan Sriwijaya dan vassal-vassalnya yang secara tradisional menjalin hubungan baik dengan Cina dipaksa untuk menjadi aliansi Kertanegara dengan mengirimkan Ekspedisi Pamalayu pada 1273. Tampaknya ia

22 Setelah periode itu Sriwijaya mengalami kemunduran. Berdasarkan informasi dari sumber-sumber Cina dapat diketahu bahwa utusan Sriwijaya yang terakhir dikirim ke Cina pada tahun 1178. Hal itu mengindikasikan bahwa kerajaan Sriwijaya telah lemah. Kerajaankerajaan vassal Sriwijaya mulai mengirimkan utusan-utusannya sendiri ke Cina. 
mencoba untuk menyatukan Jawa dan dunia Melayu untuk menghadapi Cina.

Jika selama masa kerajaan Singasari, aliansi kekuatan politik antara Jawa dengan Melayu dilakukan dengan relatif damai, namun setelah masa kerajaan Majapahit (didirikan sejak 1292) kesatuan didirikan dengan kekuatan militer. Jika upaya raja Kertanegara untuk menyatukan dunia Melayu dengan dunia Jawa terutama ditujukan untuk menghadapi bahaya ekspansi eksternal (dari Cina), kesatuan Majapahit ini terutama didorong oleh ambisi untuk menundukkan kekuasaan politik lokal di bawah bendera integrasi Majapahit. Dengan menerapkan kebijakan seperti itu, Majapahit bisa 'mewarisi' sebagian besar bekas wilayah Sriwijaya. ${ }^{23}$ Meskipun tampaknya Majapahit tidak

23 Sumber tradisional dari pertengahan abad keempat belas, seperti Pararaton (1350) dan Negarakertagama (1365), menyediakan banyak informasi mengenai berbagai tempat yang diklaim dan dikuasai oleh kerajaan Majapahit. Tempat-tempat ini mencakup Palembang, Jambi, Kampar, Siak, Rokan, Lamuri, Barus, Haru di Sumatera; Pahang, Kelang, Sai dan Trenggano di Semenanjung Malaya; Sampit, Kapuas, Barito, Kutai dan Sedu di Kalimantan; Butung, Luwuk, Banggai , Tabalong dan Sedu di Sulawesi; Wandan di Maluku; Seran di Irian; Sumba dan Timor di pulau-pulau Nusatenggara. Meskipun daftar kapal Majapahit diragukan, ada bukti kuat bahwa tempat-tempat yang disebutkan dalam sumber-sumber yang dihubungkan oleh sebuah jaringan maritim. Lihat A.B. Lapian, 'The maritime network in the Indonesian archipelago in the fourteenth century', dalam: SEAMEO Project in Archeology and Fine Arts SPAFA, FinalRreport: Consultative Workshop on Research on Maritime Shipping and Trade Networks in Southeast Asia (Cisarua, West Java, Indonesia: 20-27 November 1984), hlm. 71-80. mampu secara terus-menerus mengontrol Selat Malaka, tetapi sejauh ini Majapahit dipercaya sebagai kerajaan yang terbesar dan terkuat di antara negara-negara Jawa, dan tidak tidak memiliki saingan yang berarti di Nusantara selama lebih dari satu abad.

Pertikaian internal kerajaan Majapahit pada akhir abad ke-14 telah menyebabkan daerah-daerah vassal Majapahit memerdekakan diri. Salah satu bekas vassal Majapahit yang terletak di jantung dunia Melayu, Malaka, juga melepaskan diri dari Majapahit. Munculnya Malaka sebagai sebuah negara merdeka di akhir abad ke-14 segera menjadi pusat perdagangan dunia Melayu. Bangkitnya Malaka dapat diasumsikan untuk menggantikan peran yang sebelumnya dimainkan oleh Sriwijaya. Perkembangan Malaka diuntungkan oleh dua kondisi yaitu terjadinya proses kehancuran kerajaan Majapahit sebagai akibat pertikaian internal dan perlindungan kaisar Cina dari ancaman yang datang dari Ayutthaya yang mulai mengembangkan kekuatan militer mereka ke selatan. Selama periode itu, Cina aktif untuk patroli ke kawasan Nanyang (daerah selatan) yang dipimpin oleh komandan Cheng-Ho.

Selain itu, perkembangan Malaka juga seiring dengan semakin meningkatnya peran para pedagang muslim di sepanjang Jalur Sutra maritim antara Timur Tengah dan Asia Tenggara. Dengan memeluk Islam, 
penguasa Malaka berhasil menarik dukungan politik dan dukungan ekonomi dari pedagang muslim. Dalam waktu singkat Malaka menjadi pusat kegiatan perdagangan di Asia Tenggara. Pelabuhan ini segera berfungsi sebagai titik transit komoditi dari kepulauan Indonesia dan kemudian didistribusikan ke timur dan / atau ke barat.

Sementara itu, Jawa juga mengalami perkembangan yang menarik. Islam mulai merambah kehidupan politik dan sosial di kawasan patura Jawa sehingga menyulitkan Majapahit dalam mempertahankan kekuasaannya di jantung Pulau Jawa. Sejak abad ke-15, keseimbangan kekuasaan di Nusantara menjauh dari kerajaan Majapahit dan kota-kota pelabuhan di pantura Jawa satu per satu masuk Islam dan ditarik ke dalam orbit komersial Malaka. Hal ini sejalan dengan kedatangan Portugis di awal abad ke-16 ketika kerajaan Majapahit hanya bertahan sebagai negara pedalaman kecil di bagian timur Jawa.

Sejalan dengan proses integrasi politik, difusi sosial dan budaya juga terjadi. Selain memanfaatkan saluran politik, difusi budaya juga terjadi melalui aktivitas perdagangan, migrasi, pendidikan Islam, penggunaan bahasa Jawa di pesantren, dan lain-lain. Ekspansi politik ekspansi dan aktivitas pelayaran dan perdagangan memungkinkan terjadinya migrasi berbagai kelompok-kelompok etnis di kawasan Nusantara. Dalam hal ini peranan orang
Jawa dapat dilihat di Malaka sebagai pusat perdagangan terbesar di Nusantara menjelang kedatangan bangsa-bangsa Barat. Schrieke mengatakan bahwa perdagangan di Nusantara pada waktu itu 'largerly in Javanese hands'. ${ }^{24}$ Sementara itu MeilinkRoelofsz menyatakan bahwa Malaka yang merupakan pasar internasional terbesar di Nusantara di mana 84 bahasa digunakan setiap hari didominasi oleh dua dua kelompok pedagang paling kaya dan paling berkuasa yaitu orang-orang India dan orang Jawa. ${ }^{25}$ Dengan demikian hubungan dagang antara pantai utara Jawa dengan Malaka menjadi sangat erat. ${ }^{26}$

Pendidikan dan penyebaran Islam juga menjadi fondasi bagi pengaruh budaya Jawa di luar Jawa. Di samping Aceh dan Minangkabau, pengaruh Islam dari Jawa di wilayah sekitar Laut Jawa juga signifikan. Meskipun keberadaan Islam di Jawa sendiri masih kecil dibandingkan Islam di Aceh (Samudra Pasai) misalnya, pelembagaan pendidikan Islam di Jawa, yaitu pesantren lebih berkembang daripada di tempattempat lain di Nusantara. Sejak abad ke-15 salah satu kota di pantura Jawa, yaitu Gresik

24 B. Schrieke, Indonesia Sociological Studies (Bandung: Van Hoeve, 1957), hlm. 64.

25 M.A.P. Meilink-Roelofsz, Asian Trade and European Influence in the Indonesian Archipelago between 1500 and about 1630 (The Hague: Nijhoff, 1962), hlm. 37, 55.

${ }^{26}$ Nordin Hussin, Trade and Society in the Straits of Melaka: Dutch Melaka and English Penang, 1780-1830 (Singapore: NUS Press \& NIAS Press, 2007), hlm. 10-11. 
(Pesantren Giri), menjadi pusat penting pendidikan Islam di Nusantara. Muridmurid pesantren ini tidak hanya dari Jawa tetapi juga dari berbagai daerah di Kepulauan Indonesia, bahkan dari dunia Melayu. Pesantren ini didirikan oleh Sunan Giri (Raden Paku) yang diyakini sebagai salah satu Wali Songo di Jawa. ${ }^{27}$

Sangat menarik bahwa bahasa Jawa, bukan bahasa Melayu, digunakan sebagai media pengajaran di pesantren. Murid (santri) dari berbagai daerah di Nusantara harus belajar bahasa Jawa sebelumnya sebelum belajar hukum Islam di pesantren. Ini berarti bahwa lebih banyak orang dari luar Jawa belajar kebudayaan Jawa termasuk cara berpikir dan berperilaku orang Jawa. Ketika murid-murid kembali ke daerah mereka sendiri setelah menyelesaikan studi, mereka menyebarkan pengetahuan Islam dalam bahasa campuran, antara bahasa lokal dan Jawa. Jika bahasa Melayu diakui sebagai lingua franca untuk kegiatan perdagangan, bahasa Jawa digunakan untuk lingua franca dunia pendidikan Islam di kepulauan Indonesia.

Tampaknya secara politis, proses integrasi yang dilaksanakan oleh kerajaankerajaan Jawa, di beberapa kasus, dapat dipahami oleh beberapa unsur-unsur lokal sebagai kekuatan eksternal yang dapat memberikan rasa bangga dan wewenang

\footnotetext{
Menara, 1979).
}

kepada kekuatan lokal. Mereka merasa telah disahkan oleh kekuatan politik dan militer besar dari Jawa. Beberapa sumber sejarah lokal dari daerah-daerah sekitar Laut Jawa bercerita tentang kekuatan politik lokal yang bangga menjadi bagian dari integrasi Jawa. Selain itu, beberapa penguasa lokal di wilayah sekitar Laut Jawa juga bangga jika mereka bisa menikah dengan keluarga kerajaan Jawa dan akhirnya mereka mendapat gelar bangsawan dari Raja Jawa. ${ }^{28}$

Hal ini juga sangat menarik bahwa kehadiran unsur-unsur budaya Jawa di daerah-daerah di luar Jawa bukan hanya diterima untuk memperkaya budaya lokal tetapi juga menjadi semacam simbol prestisius. Bahkan, hal-hal yang di Jawa hanya digunakan sebagai koin yang bergambar tokoh pewayangan Semar misalnya, digunakan sebagai jimat di Kelantan. Masyarakat setempat menyebut koin sebagai 'amulet Jawa' atau 'fetis Jawa' atau 'jimat Jawa'. Barang ini diyakini mampu menyembuhkan berbagai penyakit. 29

Uraian di atas memberikan gambaran yang cukup jelas bahwa sebelum dominasi kolonialisme Belanda, kekuatan maritim yang berbasis di pantura Jawa memiliki andil yang signifikan dalam ikut menentukan dinamika kebaharian di

${ }^{28}$ Hal ini bisa dilihat dalam banyak cerita yang dipaparkan dalam kitab Sejarah Melayu. Lihat Abdullah (ed.) Sedjarah Melayu (Djakarta: Djambatan, 1958), hlm. 145.

29 A. Rentse, 'Majapahit Amulets in Kelantan', JMBRAS 14 (1936), hlm. 300-304. 
perairan Nusantara. Dinamika kebaharian itu telah memungkinkan terjadinya hubungan-hubungan lintas budaya di antara berbagai kelompok etnis yang ada di Nusantara baik melalui aktivitas diplomasi politik, militer, perdagangan, penyebaran agama, unsur-unsur budaya, dan sebagainya. Namun demikian sayang sekali bahwa peran masyarakat nelayan masih terasa berada di tempat yang marginal. Peran-peran besar itu biasanya dipegang oleh kelompok pedagang, pelaut, bisnismen, dan sebagainya.

\section{Perkembangan Sistem Pengetahuan dan Teknologi}

Sebagaimana yang telah disinggung dalam bagian pendahuluan bahwa sebagai sebuah kategori entitas kultural, masyarakat nelayan sudah mengembangkan 'budaya nelayan' yang sebetulnya merupakan genre tertentu dari budaya bahari secara umum. Sebagai sebuah kategori kultural, budaya nelayan juga memenuhi tujuh unsur kebudayaan, termasuk di dalamnya adalah sistem pengetahuan dan teknologi. Bahkan bisa dikatakan bahwa matapencaharian nelayan merupakan aktivitas ekonomi yang paling tua dalam ekonomi maritim sehingga di samping memiliki sistem pengetahuan tertentu yang berkaitan dengan kenelayanan juga meiliki teknologi dan alatalat produksi dalam konteks perikanan. Oleh sebab itu, bagian ini akan mengkaji sistem pengetahuan dan teknologi pada masyarakat nelayan di pantura Jawa secara umum.

Seperti diketahui bahwa di Nusantara pun aktivitas mencari dan mengumpulkan sumber daya pangan yang berasal dari laut tentunya sudah ada jauh sebelum datangnya pengaruh India dan sudah dilakukan oleh berbagai komunitas historis yang mendiami pulau-pulau di Nusantara sejak ribuan tahun yang lalu. Hal itu mudah dipahami mengingat bahwa sebagai penghuni kawasan bahari tentunya mereka sangat akrab dengan dunia laut. Peninggalan arkeologis dari Jaman Batu Pertengahan (messolithikum) yang disebut sebagai kjokkenmoddinger atau secara harafiah diterjemahkan sebagai sampah dapur, yaitu sampah-sampah dapur yang sudah memfosil yang berasal dari kulit kerang dan tulang berbagai binatang laut yang merupakan sisa-sisa makanan jaman batu, menunjukkan betapa nenek moyang bangsa Indonesia dahulu sudah memanfaatkan sumber daya bahari sebagai bahan makanan mereka. Hal itu juga berarti bahwa kenelayanan sudah merupakan bagian dari sistem mata pencaharian hidup mereka.

Namun demikian aneh sekali bahwa mata pencaharian hidup kenelayanan sebagai mata pencaharian hidup tertua dalam masyarakat mahari ini mengalami perkembangan yang sangat lamban. Hal ini barangkali juga terkait dengan kemajuan pengetahuan dan teknologi serta alat 
produksi, khususnya yang terkait dengan pengetahuan dan teknologi penangkapan dan pengawetan produk perikanan. Oleh karena itu meskipun pemanfaatan produk laut sebagai bahan pangan yang dihasilkan oleh kegiatan kenelayanan sudah dikenal sejak jaman batu namun selama ribuan tahun belum berkembang sebagai komoditas yang mampu mendominasi kehidupan kemaritiman, misalnya sebagai komoditas dagang yang penting. Oleh karena itu perlu dikaji perkembangan sistem pengetahuan dan teknologi dalam budaya masyarakat nelayan.

\section{A. Sistem Pengetahuan}

Sebagai suatu sistem mata pencaharian tertua di bidang kebaharian, mata pencaharian nelayan sudah memiliki sistem pengetahuan yang cukup established. Sistem pengetahuan dalam budaya masyarakat nelayan ini mengalami perkembangan dari waktu ke waktu. Namun demikian sudah barang tentu untuk melacak secara tepat tahap-tahap perkembangan sistem pengetahuan pada masyarakat nelayan sulit untuk dilakukan. Hal itu dikarenakan proses transmisi pengetahuan kenelayanan dari generasi ke generasi berjalan tanpa banyak meninggalkan catatan atau dokumen yang memungkinkannya untuk dilacak perkembangannya. Dalam makalah ini hanya akan dideskripsikan mengenai sistem pengetahuan masyarakat nelayan yang ada kaitannya dengan dunia kenelayanan atau aktivitas penangkapan dan pemanfaatan ikan. Ada beberapa pengetahuan tradisional dalam budaya nelayan yang akan difokuskan dalam makalah ini, yaitu pengetahuan tentang posisi dan arah di tengah laut, pengetahuan tentang cuaca, dan arah angin.

Pengetahuan tentang Posisi dan Arah di Tengah Laut

Bagi nelayan dan pelaut modern, untuk mengetahui posisi dan arah di tengah laut bukan merupakan sesuatu yang sulit. Mereka dapat menggunakan peralatan yang canggih. Untuk mengetahui posisi geografis, mereka dapat menggunakan GPS (Geographical Positioning System) yang memungkinkan mereka dapat mengetahui posisi geografis di mana mereka berada dengan mengetahui letak pada posisi lintang ataupun bujur secara tepat. Di samping itu nelayan sekarang sudah menggunakan kompas yang memungkinkan mereka mengetahui secara tepat arah mata angin sehingga tidak mungkin salah arah atau 'kesasar' di tengah laut meskipun pada malam hari.

Namun demikian para nelayan tradisional jaman dulu belum mengenal GPS dan kompas. Pertanyaannya adalah bagaimana mereka mengetahui posisi dan arah di laut sehingga mereka bisa pulang kembali ke kampung halamannya dan tidak 'kesasar' atau tersesat. Dalam hal ini, para 
nelayan tradisional menggunakan gejalagejala dan kejadian alam untuk dapat mengetahui posisi mereka dan arah ke mana mereka akan pergi. Gejala alam tersebut antara lain puncak gunung yang dapat dilihat dari laut dan letak bintang di langit.

Jika puncak gunung hanya dapat digunakan pada siang hari dan dengan jarak pandang yang terbatas maka letak bintang dapat dimanfaatkan pada malam hari ketika cuaca tidak mendung ataupun hujan. Dalam hal ini rasi bintang yang dapat dengan mudah dipakai sebagai penanda dan sekaligus petujuk arah adalah rasi bintang salib selatan atau zuiderkruis atau Crux atau di Jawa disebut sebagai 'lintang gubug penceng' (bintang gubug miring). Rasi bintang ini terletak di belahan bumi bagian selatan. Jika orang dalam perjalanan kehilangan arah di malam hari, maka ia dapat melihat kedudukan rasi bintang ini. Bentuk rasi bintang ini seperti layanglayang. Cara untuk menentukan titik selatan adalah dengan menarik garis lurus bintang yang paling atas ke arah bumi melalui bintang yang paling bawah. Unjung garis dan terusannya adalah titik selatan yang sesungguhnya. ${ }^{30}$ Di sepanjang pantura Jawa,

30 Namun jika orang berada pada belahan bumi bagian utara, di sebagian tempat tidak akan terlihat rasi bintang gubug penceng karena bumi berbentuk bulat. Sebagai gantinya, di belahan bumi bagian utara akan terlihat rasi bintang Ursa Mayor. Pada ujung Ursa Mayor terdapat bintang Polaris. Seandainya ada orang berdiri di titik Kutub Utara dan menengadah ke keberadaan bintang Gubug Pnceng ini sangat terkenal karena daerah ini merupakan kawasan yang terletak di kawasan belahan bumi bagian selatan.

\section{Pengetahuan tentang Iklim dan Cuaca}

Tidak sulit bagi nelayan modern untuk mengetahui cuaca di tengah lautan pada hari tertentu. Bahkan cuaca beberapa hari mendatang dapaty diketahui dengan baik sehingga mereka dapat mempertimbangkan untuk telap melaut atau menunda terlebih dahulu sehubungan dengan cuaca yang tidak menguntungkan. Dalam hal ini mereka dapat mencari informasi di kantor BMG (Badan Meteorologi dan Geofisika). Bahkan mereka dapat memperoleh informasi tentang cuaca tersebut melalui siaran televisi ataupun radio. Namun demikian hal semacam itu tidak bisa diperoleh oleh nelayan tradisional jaman dahulu karena belum ada BMG yang sudah menggunakan perangkat yang canggih. Bagi nelayan tradisonal jaman dahulu, untuk mengetahui keadaan atau perubahan cuaca dan iklim digunakan pertanda dan gejalan alam misalnya kemunculan dan letak rasi bintang tertentu, arah dan sifat angin, kilatan cahaya di langit, dan sebagainya. Pengetahuan tentang gejalan alam semacam ini sangat penting

langit maka tepat di atas ubun-ubunnya adalah Bintang Polaris. Lihat "Bintang", dalam: file://localhost/C:/Users/LABSEJ 1/AppData/L ocal/Temp/BINTANG.pdf (Dikunjungi tanggal 15 Juni 2010. 
bagi para nelayan karena dengan pengetahuan dan pengalaman yang tepat, para nelayan akan dapat bertindak dengan tepat pula sehingga mereka akan mendapatkan penghasilan yang banyak dan dapat dihindari adanya berbagai bencana di laut seperti badai. Dengan memiliki kemampuan untuk dapat melihat gejalagejala alam seperti itu para nelayan tradisional jaman dahulu dapat meprediksikan keadaan yang akan terjadi misalnya waktu musim ikan atau sebaliknya paceklik ikan, musim ombak besar, dan sebagainya.

Kemunculan Lintang Waluku atau Orion yang ditandai dengan bertiupnya angin timur laut, misalnya, dijadikan sebagai patokan untuk memulai masa tanam bagi petani. ${ }^{31}$ Dengan adanya musim angin timur lain ini, para nelayan mulai hati-hati untuk mencari ikan di laut karena ombak diperkirakan akan besar. Dalam pandangan orang Jawa, rasi bintang Orion ini digambarkan berbentuk seperti waluku atau bajak yang sedang ditarik oleh sapi ataupun kerbau.

Sementara itu jika Lintang Wunoh muncul di cakrawala sebelah timur laut dalam suasana remang-remang, maka diperkirakan akan terjadi cuaca buruk sehinga nelayan tidak berani turun ke laut. Sebaliknya jika Lintang Wunoh ini muncul

\footnotetext{
"Astronomi", dalam: http://id.wikipedia.org/wiki/Astronomi (dikunjungi tanggal 15 Juni 2010).
}

dalam suasana yang terang maka nelayan dengan suka-cita mencari ikan di laut. Lintang Wunoh ini akan selalu bergerak ke arah barat daya sedangkan Lintang Waluku bergerak dari timur ke barat dengan arah yang lurus. Sementara itu jika bintang Gubug Penceng mulai terlihat dipandang menandakan bahwa musim ikan telah mulai tiba dan para nelayan dapat mempersiapkan dan memperbaiki peralatan untuk turun ke laut. Bintang Gubug Penceng yang muncul terutama pada bulan Mei, Juni dan Juli ini oleh para nelayan diyakini bergerak ke arah barat daya. ${ }^{32}$

Sementara itu masyarakat nelayan tradisional di kawasan Rembang juga mengenal adanya 'Lintang lanjar'. Apabila bintang ini menampakkan diri maka masyarakat menandai akan datangnya musim angin keras yang disertai dengan hujan lebat yang disebut dengan istilah 'barat lanjar', artinya angin kencang yang disebabkan oleh munculnya 'lintang lanjar'. Kalau sudah demikian, para nelayan tidak berani melaut untuk mencari ikan ke lepas pantai. Jika mereka terpaksa melaut biasanya hanya di pantai saja dan apabila mulai muncul awan, mereka segera menepi karena takut datangnya angin dan ombak. ${ }^{33}$

32 D.A. Rinkes, N. Van Zalinge,J.W. De Roever (eds), Het Indische Boek der Zee (Batavia: Kolff, 1925), hlm. 30.

33 Akhmad Solihin, "Mencermati Program Relokasi Nelayan", Pikiran Rakyat ( 10 Januari 2004), dalam: http://ikanbijak.wordpress.com/2008/03/14/ 
Kilatan cahaya yang muncul di ufuk timur pada sore hari ketika cuaca sedang terang juga merupakan bagian dari pengetahuan masyarakat nelayan. Gejala alam seperti itu dipahami sebagai sebuah pertanda kemungkinan terjadinya gelombang besar. Jika para nelayan di tengah lautan melihat gejala semacam itu maka mereka segera buru-buru untuk pulang karena takut akan terhantanm oleh gelombang besar. ${ }^{34}$

Adalah suatu yang menarik bahwa sistem pengetahuan pada masyarakat nelayan tradisional dibangun dengan cara mencermati gejala-gejala alam secara siklis berulang-ulang. Mereka memiliki pengetahuan bahwa peredaran bulan yang merupakan gejala alam digunakan sebagai patokan. Pada masa petengan periode paroh kedua dari setiap bulan, yaitu sekitar tanggal 15 hingga awal bulan berikutnya (sistem kalender Jawa) diyakini bahwa ikan akan banyak bermunculan di laut. Dengan demikian para nelayan betul-betul menyiapkan segala sumber daya yang ada untuk mencari ikan di laut. Sebaliknya pada masa wulan benter tidak akan banyak ikan bisa dijumpai di laut sehingga seringkali para nelayan agak enggan untuk melaut. Selain itu pemahaman siklis ini juga dimiliki oleh para nelayan. Menurut pengetahuan

mencermati-program-relokasi-nelayan/ (Dikunjungi tanggal 16 Juni 2010).

34 A.M. Djuliati Suroyo, dkk., Sejarah dan Budaya Maritim di Lasem (Semarang: Laporan Penelitian UNDIP, 1994), hlm. 58. mereka, musim ikan berubah-uabah secara siklis selama tiga bulanan tanpa terikat pada perhitungan bilan dalam kalender. Jika dalam rentang waktu tiga bulan mereka menikmati panen ikan secara besar-besaran maka pada tiga bulan berikutnya akan mengalami masa sulit ikan. Namun demikian masa sulit ikan selama tiga bulan tersebut akan segera disusul oleh masa panen ikan selama tiga bulan berikutnya dan seterusnya. ${ }^{35}$

\section{Pengetahuan Arah Arus dan Angin}

Pengetahuan mengenai arah angin dan arus di tengah lautan juga sangat penting bagi nelayan tradisional pada jaman dulu. Jika mereka tidak memiliki pengetahuan itu maka niscaya mereka akan menghadapi kesulitan di laut dan bahkan tidak bisa pulang ke kampung mereka. Sudah barang tentu pengetahuan semacam ini juga dimiliki oleh masyarakat nelayan secara umum. Menarik sekali hasil penelitian yang dilakukan oleh antropolog Gene Ammarel dari Ohio University Amerika serikat. Salah satu kutipan hasil penelitiannya yang menunjukkan pengetahuan para pelaut tradisiomal Mandar, antara lain sebagai berikut: ${ }^{36}$

\section{Ibid., hlm. 59.}

36 "Resensi - Navigasi Bugis: Sebuah Pengetahuan Kebaharian Indonesia", dalam: http://beritadaerah.com/artikel.php?pg=artikel national\&id=10207\&sub=Artikel\&page=17 (Dikunjungi tanggal 15 Juni 2010). 
"... Seiring diangkatnya sauh, saya bertanya ke arah manakah arus bergerak? Yang mengejutkan saya, Najamuddin tidak melihat ke laut yang dangkal dan berhias terumbu. Melainkan, seakan tertuntun secara refleks, matanya terangkat ke langit dan, sementara menyapukan pandangan dari satu cakrawala ke cakrawala lain, dia bertanya seperti sedang berpikir keras, "Bulan di mana?" Akhirnya diketahui, bulan berusia sembilan hari belum terbit pukul 10 pagi saat kami berangkat. Demi mengetahui bahwa air sedang surut, dia mencatat bahwa arus sedang mengalir ke barat ..."

Tampaknya pengetahuan serupa juga dimiliki oleh para nelayan tradisional di pantai utara Jawa. Untuk mengetahui arah angin jika sedang di tengah lautan, para nelayan tradisional cukup mengamati gerak ombak itu sendiri. Mereka memiliki pengetahuan bahwa ombak bergerak dengan arah yang tetap pada musim-musim tertentu. Gejala alam yang berulang-ulang ini kemudian dijadikan sebagai patokan. Mereka juga memiliki pengetahuan bahwa sebelum ombak datang mereka sudah bisa mendeteksi dengan mengamati arus yang sedang bergerak. Biasanya angin datang setelah ombak datang. Jika mereka kihilangan arah pada siang hari, biasanya mereka masih memiliki patokan yang berupa puncak gunung seperti gunung Ceremai di daerah Cirebon, Gunung Slamet untuk daerah Jawa Tengah bagian barat,
Gunung Sindoro, Sumbing, dan Prahu untuk daerah pantai Pekalongan dan sekitarnya, Gunung Ungaran untuk kawasan Semarang dan sekitarnya, Gunung Muria untuk daerah Jepara, Gunung Lasem untuk daerah Rembang dan sebagainya. ${ }^{37}$

Pada bulan November hingga sekitar Februari biasanya angin dan ombak datang dari arah timur laut. Sebaliknya pada musim kemarau yang biasanya berlangsung sejak bulan April hingga Oktober, angin dan ombak akan bergerak dari arah barat laut. Di kawasan patai utara Jawa, jika pada malam hari yang cerah, arah timur dapat diketahui dengan cara melihat bintang yang oleh para nelayan disebut sebagai 'Lintang Pating' yaitu sebuah bintang besar yang tidak pernah berubah posisinya.

\section{B. Sistem Teknologi dan Alat Produksi}

Sebagai sebuah kategori budaya, nelayan juga sudah mengembangkan sistem teknologi dan alat produksi. Dalam hal ini sistem teknologi dan alat produksi dalam budaya masyarakat nelayan tentu saja berkaitan erat dengan sistem ekonomi nelayan yang menggantungkan pada eksploitasi sumber daya bahari yang berupa perikanan dan sejenisnya. Sebagai matapencaharian tertua dalam masyarakat bahari, kenelayanan atau perikanan tentu saja sudah memiliki sistem teknologi dan alat produksi secara turun-temurun. Sudah

37 Findlay, A directory, hlm. 639-655. 
barang tentu sistem teknologi dan alat produksi tersebut mengalami perkembangan dari waktu ke waktu. Teknologi dan alat produksi dalam sektor perikanan ini secara umum mencakup penangkapan, pembudidayaan dan pengolahan hasil. Namun demikian, makalah ini hanya akan memfokuskan pada sistem teknologi dan alat produksi yang dimiliki atau pernah dimiliki oleh masyarakat nelayan pantura Jawa secara umum.

\section{Teknologi Alat Tangkap}

Teknologi alat tangkap berkembang terlebih dahulu daripada teknologi budidaya, sebab pada tahap awal masyarakat pantai juga masih dapat dikategorikan sebagai masyarakat berburu dan meramu. Hanya saja jika masyarakat berburu dan meramu di pedalaman mengacu kepada perburuan binatang dan mengumpulkan makanan dari hutan maka pada masyarakat nelayan perburuan dan peramuan itu berasal dari sumber daya kelautan, yaitu berburu atau menangkap ikan di pantai. Perbedaan lain adalah bahwa jika alat berburu di pedalaman lebih sederhana yaitu hanya menyangkut persenjataan, maka peralatan berburu di laut sedikit lebih komplek di samping menyangkut peralatan tangkap juga menyangkut sarana yang khas yang berupa prahu agar mereka bisa mengarungi laut.

\section{Jukung dan Prahu}

Pada awalnya manusia pantai berburu atau menangkap ikan di pantai yang dangkal sehingga mereka tidak memerlukan prahu. Mereka cukup membawa alat tertentu seperti panah untuk menangkap ikan atau hanya dengan menggunakan tangan untuk mencari kerang. Dalam perkembangannya ketika pengetahuan dan pengalaman mereka bertambah akhirnya mereka membuat peralatan agar bisa menangkap ikan yang lebih banyak di perairan yang lebih dalam dengan menggunakan alat tertentu yang kemudian disebut prahu. Berdasarkan hasil penelitian yang dilakukan oleh Horidge dapat diketahui bahwa terdapat dua jenis prahu yang digunakan oleh nelayan yaitu jukung dan mayang. Jukung atau di kawasan kain disebut sebagai kano merupakan prahu kecil yang terbuat dari sebatang kayu yang dikeruk pada bagian tertentu sehingga dapat difungsikan untuk alat transport di laut. Di Jawa, bentuk prahu semacam ini juga disebut sebagai 'prahu lesung'. Di kawasan Asia Pasifik jenis prahu jukung ini disebut sebagai 'dug-out cano'. Sementara itu prahu mayang merupakan perahu yang dibuat dari papan kayu. Jukung ini memiliki variasi ukuran yang berbeda dan memiliki nama yang berbeda-beda pula antara satu daerah dengan daerah lainnya. Di Cirebon misalnya dikenal nama jukung lawak, di Tegal terdapat nama jukung klitik, di Semarang terdapat cemplon, di Surabaya terdapat 
jaten, sedangkan di ujung Jawa Timur dikenal adanya sampan. Karena ukurannya yang kecil dan kemampuan navigasi yang sangat sederhana maka biasanya jukung hanya digunakan di perairan pantai yang dangkal dan di teluk yang relatif tenang. ${ }^{38}$

Sementara itu jenis prahu papan yang paling populer adalah prahu mayang. Jenis prahu ini merupakan perahu tipe nelayan yang paling besar. Prahu ini digunakan untuk penangkapan ikan lepas pantai. Ukuran prahu ini mencapai panjang antara 12 sampai 20 meter dan lembar antara 3 sampai 5 meter dan biasanya dioperasikan oleh 8 sampai 30 orang. Prahu mayang dihasilkan di beberapa tempat di pantura Jawa, yaitu Cirebon, Jepara, Juana, dan Rembang. 39

Sejalan dengan perkembangan teknologi, prahu jukung mulai hilang dari peredaran karena kurang memiliki nilai ekonomis. Sementara itu prahu mayang dalam perkembangannya juga memiliki variasi dalam ukurannya. Untuk prahu yang lebih kecil seringkali disebut cukrik. Sementara itu ukuran prahu yang lebih besar disebut sebagai cantrang.

\section{Alat Tangkap}

Seperti diketahui bahwa jenis prahu yang secara umum mendominasi kawasan perairan pantura Jawa adalah prahu mayang hlm. 42

${ }^{38}$ Masyhuri, Menyisir Pantai Utara Jawa,

39 Ibid., hlm. 43. dengan berbagai versi, ukuran, dan namanya. Prahu mayang digunakan untuk menangkap ikan di lepas pantai dengan zone tangkap hingga mencapai $50 \mathrm{~km}$ dari pantai. Pada masa dulu sasaran penangkapan yang utama adalah ikan layang yang sangat berlimpah pada musimnya. Untuk menangkap ikan layang secara efisien biasanya mereka menggunakan jaring payang atau jaring payang tengah. ${ }^{40}$ Jaring payang ini mempunyai sebuah kantong di bagian tengahnya dengan bibir kantong yang dirancang secara khusus sehingga memudahkan ikan terperangkap di dalamnya dan sulit untuk bisa keluar lagi. Lubang jaring di bagian sangat lebar dan makin ke belakang makin mengerucut ke arah kantong. Payang yang besar bisa mencapai ukuran 100 meter lebih. ${ }^{41}$ Di berbagai tempat, dalam pengertian umum istilah payang juga digunakan untuk menyebut semua jenis jala. Jaring atau jala payang ini merupakan jaring yang berukuran besar yang terbuat dari bahan rami ataupun katun. Namun sebetulnya ukuran jaring payang ini disesuaikan dengan ukuran kapal dan jenis ikan yang akan ditangkap. Barangkali apa yang disebut sebagai jaring pukat harimau yang hingga sekarang dipersoalkan barangkali merupakan modifikasi dari jaring payang

\footnotetext{
40 Ibid., hlm. 47.

41 Ibid., hlm. 47.
} 
ini. Dalam hal ini jaring pukat harimau memiliki lubang-lubang yang lebih kecil sehingga ikan-ikan kecil pun ikut tertangkap. Hal ini akan persediaan ikan menjadi berkurang drastis. Pada jaman dahulu lobang-lobang pada jaring payang ini disesuaikan dengan jenis ikan yang akan ditangkap sehingga kelestarian habitat ikan dapat terjamin. Jenis jaring ini secara tradisional di buat di Lasem dan Palembang.

Jala bisa juga dioperasikan oleh satu orang nelayan saja dengan ukuran yang relatif kecil. Nelayan perorangan bisa menjala di pantai yang dangkal untuk menangkap ikan secara perorangan. Bisa juga mereka menggunakan jala dengan jukung sehingga bisa agak sedikit jauh dari garis pantai.

Selain itu, penangkapan ikan dengan pancing juga merupakan salah satu usaha para nelayan. Biasanya alat pancing ini digunakan unutk menangkap ikan-ikan jenis tertentu yang lebih besar seperti ikan tongkol, cakalang, dan tengiri. Penangkapan ikan dengan pancing ini bisa dilakukan secara individual yang tentu saja akan menghasilkan produksi yang sangat kecil dengan alat yang sederhana. Namun demikian ada juga alat pancing yang dikembangkan untuk menangkap ikan secara massal. Di kawasan pantura Jawa dikenal adanya pancing rawe. Jenis pancing ini bisa memiliki mata kail sebanyak 200 hingga 600 buah dari berbagai ukuran. Tiaptiap pancing dikaitkan pada tali sepanjang
$30 \mathrm{~cm}$ yang kemudian diikatkan dengak satu tali yang panjang. Jarak antara satu mata kail dengan mata kail yang lain sekitar 1,5 meter. Ada lagi jenis pancing massal yang disebut pancing tarik. Pancing ini menggunakan teknik yang sama dengan pancing rawe meskipun konstruksinya agak berbeda. Mata pancing langsung dikaitkan dengan satu tali yang agak besar dan memanjang yang kemudian ditarik dengan prahu. Sasaran tangkap yang diharapkan adalah ikan tongkol dan tengiri. ${ }^{42}$

Selain jaring payang dan pancing, berbagai teknologi dan alat produksi untuk penangkapan ikan di kawasan pantura Jawa juga dikenal seperti seser dan serok. Selain itu juga dikenal adanya alat perangkap ikan seperti branjang atau bagan. Dengan menggunakan bagan ini, ikan ditangkap dengan cara mengangkat ikan dari laut setelah berkumpul di jaring yang ditenggelamkan terlebih dahulu di dalam air. 43

Sejalan dengan perkembangan pengetahuan manusia, maka mereka tidak hanya berburu menangkap ikan di laut saja tetapi juga semakin lama semakin berpikir untuk membudidayakan ikan dalam rangka mencukupi kebutuhan mereka dan sekaligus untuk pengembangan ekonomi. Pada masa kerajaan Majapahit dapat diketahui secara pasti bahwa masyarakat

\footnotetext{
42 Masyhuri, ibid. hlm. 51.

43 Ibid., hlm. 53.
} 
nelayan sudah tidak hanya menangkap ikan di laut tetapi sudah membudidayakannya di tambak. Dalam Kitab Kutaramanawa diatur bahwa orang harus mentaati peraturan bahwa ikan dalam tambak diakui kepemilikannya tidak boleh diambil seenaknya oleh orang lain. Hasil tambak digunakan baik untuk konsumsi sendiri maupun untuk diperdagangkan. ${ }^{44}$

\section{Teknologi Pengawetan}

Pada awal perkembangan masyarakat berburu dan meramu, ikan yang berhasil ditangkap mungkin langsung diolah dan kemudian dimakan. Hal ini terjadi karena berbagai jenis kian merupakan bahan pangan yang cepat busuk sehingga jika tidak dilakukan sesuatu untuk mengawetkannya maka akan segera busuk.

Sejalan dengan perkembangan tingkat kemajuan masyarakat Indonesia, berbagai jenis ikan dan kerang tidak hanya ditangkap dan langsung dimakan namun juga ada kemajuan untuk mengemas produk tangkap tersebut sebagai bahan pangan yang awet. Jenis-jenis ikan tertentu dibuat menjadi terasi sebagai bumbu penyedap masakan yang sangat digemari. Mereka juga mengawetkan ikan segar menjadi ikan asin dan ikan kering. Hal ini sejalan dengan kemampuan mereka untuk melakukan

44 D.G. Stibbe, Encyclopaedie van Nederlandsch-Indië, Tweede Druk, Vierde Deel ('sGravenhage-Leiden: Martinus Nijhoff-E.J. Brill, 1921), hlm. 574. budidaya garam. Dengan adanya kemajuan teknologi pengawetan ini peroduk makanan laut tidak hanya dimakan sesaat tetapi juga dapat diperdagangkan, yaitu dalam bentuk komoditi terasi, ikan asin, dan garam. Sebelum kedatangan bangsa-bangsa Barat di Asia Tenggara beras (produk pertanian), garam dan Ikan (produk kelautan) merupakan komoditi yang paling banyak diperdagangkan dan ikan merupakan salah satu bahan pangan pokok masyarakat. ${ }^{45}$ Miguel de Loarca, orang Spanyol yang datang di Filipina pada akhir abad ke-16 mengatakan: "Penduduk pegunungan tidak bisa hidup tanpa ikan dan garam... Begitu juga penduduk pantai tidak bisa hidup tanpa beras dan kapas dari pedalaman". 46

Menangkap ikan sudah merupakan keahlian penduduk Nusantara yang dimiliki sejak lama. Oleh sebab itu tidak mengherankan ketika Cheng Ho datang di kawasan Nusantara berkomentar bahwa komoditi ikan sangat melimpah dan murah di mana-mana. 47 Bahkan orang Jawa di pedesaan masih menyebut lauk-lauk dengan sebutan iwak atau ikan laut. Hal itu menunjukkan betapa populernya iwak sebagai bahan konsumsi keseharian masyarakat. Namun demikian perdagangan ikan biasanya dalam bentuk yang sudah

45 Anthony Reid, Asia Tenggara dalam Kurun Niaga 1450-1680; Jilid I: Tanah di Bawah Angin (terjemahan Mochtar Pabotinggi) (Jakarta: Obor, 1992), hlm. 6
46 Ibid., hlm. 33.
47 Ibid., hlm. 34. 
dikeringkan atau diasinkan sehingga bisa selalu siap saji. Raffles menggambarkan bahwa paling tidak pada awal abad XIX ikan yang biasa dikonsumsi oleh penduduk jumlahnya sangat banyak. ${ }^{48}$

Garam di buat di berbagai kawasan pantai di Nusantara, seperti di Maluku, pantai Utara Jawa antara Juwana dan Surabaya. Para pelayar Belanda awal menceritakan bahwa garam sudah menjadi konsumsi dan komoditi yang sangat terkenal. Para pedagang mengangkut garam dari berbagai wilayah di pantai utara Jawa ke Sumatera (pelabuhan Baros, Pariaman, Tulang Bawang, Indera Giri, dan jambi) melalui Banten.49 Bahkan Knaap mengatakan bahwa garam merupakan produk kebaharian yang bukan hanya untuk skala lokal tetapi merupakan komoditi yang diperdagangkan dalam skala regional di kawasan Asia Tenggara. ${ }^{50}$

Selain dengan menggunakan garam, salah satu bentuk teknologi pengawetan hasil perikanan adalah adalah terasi. Meskipun pada saat ini barangkali terasi merupakan bahan pangan yang tidak populer di kalangan tertentu, namun pada

48 Thomas Stamford Raffles, The History of Java (Penerjemah Eko Prasetyaningrum, Nuryati Agustin, Idda Qoryati Mahbubah) (Jakarta: Narasi, 2008), hlm. 23.

49 Ibid., hlm. 33.

50 Gerrit J. Knaap, “A Forgotten Trade: Salt in Southeast Asia 1670-1813", dalam: Gerrit J. Knaap, Luc Nagtegaal, Roderick Ptak (eds), Emporia, Commodities and Enterpreneurs in Asian Maritime Trade, C. 1400-1750 (Wiesbanden: Steiner, 1991), hlm. 127-157). jaman dahulu produk ini sangat terkenal luas di kalangan masyarakat kepulauan. Terasi merupakan salah satu jenis makanan yang berasal dari sumber daya bahari yang paling digemari Nusantara. Pada waktu itu terasi dibuat dari ikan kering yang ditumbuk dan dibasahi, kemudian diiris-iris sesuai dengan bentuk yang diinginkan. Oleh karena merupakan salah satu jenis makanan yang favorit dan tidak semua daerah menghasilkan komiditi ini, maka terasi juga menjadi komoditi yang diperdagangkan di mana-mana baik pada masyarakat pesisir maupun pedalaman. Sambal terasi merupakan salah satu masakan favorit di hampir seluruh kawasan di Asia Tenggara. Di Malaysia, terasi disebut sebagai belacan, di Thailand disebut sebagai kapi, di Myanmar disebut nge-pee, sedangkan di Vietnam disebut sebagai nuoc-mam. ${ }^{51}$ Banyak legenda dan cerita rakyat di Jawa yang bertutur bahwa hampir setiap kota pelabuhan pada masa pra-kolonial seperti Cirebon merupakan penghasil terasi yang pada waktu itu cukup memiliki nilai yang tinggi. ${ }^{52}$ Cirebon merupakan kota pelabuhan

${ }^{51}$ Reid, ibid., hlm. 34.

52 Dalam kitab babad yang berjudul Carita Purwaka Caruban Nagari pelabuhan Pasambangan (Cirebon) pernah disinggahi oleh armada Cina di bawah pimpinan Laksamana Wai Ping dan Teng Ho dalam perjalanan mereka ke Majapahit. Selama singgah di pelabuhan ini mereka membangunkan menara mercu suar selama tujuh hari tujuh malam. Setelah selesai, oleh penguasa pelabuhan mereka diberi imbalan yang berupa garam, terasi, beras, rempahrempah, dan kayu jati. Lihat Uka Tjandrasasmita, 
pra-kolonial yang menghasilkan terasi yang sangat istimewa, yaitu terasi yang terbuat dari jenis udang kecil yang disebut rebon. Terasi rebon memiliki rasa yang lebih sedap daripada jenis terasi yang terbuat dari ikan. Selain itu masyarakat nelayan juga mengenal metode untuk pengawetan hasil tangkapan dengan cara membuat ikan asap.

Tantangan utama yang dihadapi masyarakat dalam pengolahan dan pemanfaatan ikan adalah masalah keawetan (durability). Jenis-jenis ikan merupakan bahan pangan yang cepat basi. Oleh karena itu sejalan dengan kemajuan pengalaman dalam pemanfaatan dan pengolahan ikan mulai ditemukan cara-cara untuk mengawetkannya agar dapat memiliki durabilitas yang lama sehingga dapat disimpan dan dikonsumsi untuk jangka waktu yang lebih panjang. Dengan mengunakan garam, mereka dapat mengawetkan ikan melalui penggaraman dan pengeringan. Selain itu penemuan teknologi pembuatan terasi juga merupakan terobosan tertentu yang memungkinkan sumber daya pangan bahari dapat dikonsumsi masyarakat secara luas. Demikian juga teknologi pengasapan juga merupakan upaya untuk mengawetkan ikan agar dapat disimpan dalam waktu yang relatif lama. Dengan penemuan teknologi

"Bandar Cirebon dalam Jaringan Pasar Dunia", dalam: Susanto Zuhdi (Penyunting), Cirebon sebagai Bandar Jalur Sutera: Kumpulan Makalah Diskusi Ilmiah (Jakarta: Departemen Pendidikan dan Kebudayaan, 1996), hlm. 201. pengawetan terhadap ikan ini maka pengonsumsian ikan tidak hanya terbatas di daerah pantai saja tetapi juga jauh mencapai daerah pedalaman.

\section{Catatan Akhir}

Dari uraian di atas, dapat dirumuskan beberapa catatan penting:

1. Bahwa budaya masyarakat nelayan merupakan 'sea-side culture' yang paling tua dalam khasanah budaya bahari.

2. Meskipun dalam sejarah budaya masyarakat nelayan di pantai utara Jawa mengalami perkembangan yang lamban jika dibandingkan dengan sektor kebaharian yang lain (seperti perkapalan dan perdagangan) namun budaya masyarakat nelayan juga mengalami perkembangan sejalan dengan modernisasi yang merebak di sektorsektor yang terkait.

3. Faktor ekologis telah memprekondiskan corak budaya nelayan merupakan budaya yang khas jika dibandingkan dengan berbagai komunitas di sekitarnya.

4. Kekhasan budaya nelayan dapat dilihat antara lain dari unsur budaya yang terkait dengan sistem pengetahuan, teknologi, dan ekonomi mereka, seperti sistem bagi hasil, pengetahuan tentang posisi dan arah di tengah laut, iklim dan cuaca, arah arus dan angin, teknologi 
prahu, berbagai jenis alat tangkat, dan teknologi pengolahan ikan.

\section{DAFTAR PUSTAKA}

Abdullah (ed.) 1958. Sedjarah Melayu. Djakarta: Djambatan.

A. Dwihendrosopno, 2009. "Dampak Modernisasi Alat Tangkap Ikan Terhadap Sistem Bagi Hasil Nelayan Di Desa Gempolsewu Kecamatan Rowosari Kabupaten Kendal", artikel Hibah Penelitian Jurusan Sejarah Fakultas Ilmu Humaniora Universitas Diponegoro.

A.G. Findlay, 1889. A Directory for the Navigation of the Indian Archipelago and the Coast of China from the Straits of Malacca and Sunda, and thePpassage East of Java to Canton, Shanghai, the Yellow Sea, and Korea. London: Laurie.

A. Rentse, 1936. 'Majapahit Amulets in Kelantan', JMBRAS 14

Akhmad Solihin, "Mencermati Program Relokasi Nelayan", Pikiran Rakyat ( 10 Januari 2004), dalam: http://ikanbijak.wordpress.com/2 008/03/14/mencermati-programrelokasi-nelayan/ (Dikunjungi tanggal 16 Juni 2010).

A.M. Djuliati Suroyo, dkk., 1994. Sejarah dan Budaya Maritim di Lasem. Semarang: Laporan Penelitian UNDIP.

Anthony Reid, 1992. Asia Tenggara dalam Kurun Niaga 1450-1680; Jilid I: Tanah di Bawah Angin (terjemahan Mochtar Pabotinggi). Jakarta: Obor.

Bondan Kanumoyoso, dkk. 2009. (peny.), Kembara Bahari: Esei Kehormatan 80 Tahun Adrian B. Lapian. Jakarta: Komunitas Bambu.
B. Sadhotomo \& J.R. Durand, "General Features of Java Sea Ecology", dalam:

file://localhost/C:/Users/LABSEJ 1/AppData/Local/Temp/0100172 48.pdf (Dikunjungi tanggal 15 Juni 2010).

B. Schrieke, 1957. Indonesia Sociological Studies. Bandung: Van Hoeve.

D.A. Rinkes, N. Van Zalinge,J.W. De Roever (eds), 1925. Het Indische Boek der Zee. Batavia: Kolff.

D.G.E. Hall, 1988. Sejarah Asia Tenggara. Surabaya: Usaha nasional.

D.G. Stibbe, 1921. Encyclopaedie van Nederlandsch-Indië, Tweede Druk, Vierde Deel 's-Gravenhage-Leiden: Martinus Nijhoff-E.J. Brill.

Gerrit J. Knaap, "A Forgotten Trade: Salt in Southeast Asia 1670-1813", dalam: Gerrit J. Knaap, Luc Nagtegaal, Roderick Ptak (eds), 1991. Emporia, Commodities and Enterpreneurs in Asian Maritime Trade, C. 1400-1750

H.G. Quaritch Wales, 1978. 'The Extent of Srivijaya's Influence Abroad', JMBRAS 1 (51)

H. Blink, 1907. Nederlandsch Oost- en WestIndië: Geographisch, Etnologisch en Economisch Beschreven, tweede deel. Leiden: Brill.

Koentjaraningrat, 1990.Pengantar Ilmu Antropologi. Jakarta: Rineka Cipta.

M.A.P. Meilink-Roelofsz, 1962. Asian Trade and European Influence in the Indonesian Archipelago between 1500 and about 1630. The Hague: Nijhoff.

Masyhuri, 1996. Menyisir Pantai Utara Jawa: Usaha dan Perekonomian Nelayandi Jawa dan Madura, 1850-1940. Jakarta: Pusaka Nusatama. 
Nordin Hussin, 2007. Trade and Society in the Straits of Melaka: Dutch Melaka and English Penang, 1780-1830. Singapore: NUS Press \& NIAS Press.

O.W. Wolters, 1979. 'Studying Srivijaya', JMBRAS 2 (52).

Pujo Semedi, 2003. Close to the Stone, Far from the Throne: The Story of $A$ Javanese Fishing Community 1820s1990s. Yogyakart: Benang Merah.

Sugiyarto, "Perubahan Pandangan Bekerja Masyarakat Nelayan Desa Ujungwatu, Jepara", dalam: http://www.google.co.id/search?q =ujung+watu+jepara\&ie=utf-

8\&oe $=$ utf-8\&aq $=$

t\&rls=org.mozilla:id:official\&client= firefox-a

Susanto Zuhdi (Peny.), 1996. Cirebon sebagai Bandar Jalur Sutera: Kumpulan Makalah Diskusi Ilmiah. Jakarta: Departemen Pendidikan dan Kebudayaan..

Sutejo K. Widodo, 2005. Ikan Layang Terbang Menjulang: Perkembangan Pelabuhan Pekalongan menjadi Pelabuhan Perikanan1900-1990. Semarang: BP UNDIP-Toyota Foundation.

Thomas Stamford Raffles, 2008.The History of Java (Penerjemah Eko Prasetyaningrum, Nuryati Agustin, Idda Qoryati Mahbubah). Jakarta: Narasi.

Umar Hasyim, 1979. Sunan Giri. Kudus: Menara.

William D. Sunderlin, "Beyond Mathusian Overfishing: The Importance of Structural and Non-demographic Factors", Traditional Marine Resources Management and Konowledge Information Bulletin (4 September 1994).
W. Rodhes (ed.), 1966. The Encyclopedia of Oceanography. New York: Reinhold 